\title{
Markéta Pánková, Jan Amos Komenský $v$ českém a světovém výtvarném umění (1642-2016), Academia - Národní Pedagogické Muzeum a Knihovna J.A. Komenského, Praha 2017, ss. 267 (Marceli Kosman)
}

Jan Amos Komeński jest postacią monumentalną w dziejach czeskich, posiada w swoim kraju pomniki, muzea, zaś w Nowym Jorku pod pieczą uczonych ze swej ojczyzny działa światowe Towarzystwo jego imienia oraz ukazuje się czasopismo Comenius. Journal of Euro-American Civilisation. Między Pragą i Holandią, gdzie XVII-wieczny uczony spędził ostatnie lata i zakończył życie, rozwijane są ścisłe kontakty, podobnie jak z wielkopolskim Lesznem, z którym po przymusowym opuszczeniu kraju ojczystego podczas wojny trzydziestoletniej był związany w latach 1628-1656, a później (do dziś dnia!) pielęgnowana była pamięć o tym pobycie. Od 1972 r. imię znakomitego pedagoga nosi ówczesne Liceum Ekonomiczne (obecny Zespół Szkół Ekonomicznych), od końca minionego tysiąclecia Państwowa Wyższa Szkoła Zawodowa (w oddzielnym budynku znajduje się Aula Comeniana, Dom Studencki nosi nazwę Komenik, w bibliotece uczelnianej znajduje się galeria pod tym samym imieniem), a w latach 1947-1969 Komeński patronował ówczesnemu Państwowemu Liceum Pedagogicznemu.

Pomnik Komeńskiego znajduje się przed gmachem wspomnianej PWSZ, jego popiersie na klatce schodowej Zespołu Szkół Ekonomicznych, a znacznie starszą metrykę ma monument wzniesiony w 1898 r. przed kościołem św. Jana; pomnik, w 1947 r. ulokowano na placu Jana Amosa Komeńskiego, który właśnie wówczas otrzymał obecną nazwę. Są to dowody przywiązania do tej postaci, towarzyszące zainteresowaniu badaczy (konferencje i publikacje naukowe) i popularyzatorów. 
Z pewnością wiele miejsca zajęłoby dziś podsumowanie wiedzy o tej monumentalnej postaci na leszczyńskiej niwie, na której poczesne miejsce zajmują teksty na łamach dotychczasowych tomów „Rocznika Leszczyńskiego”.

Żywa i nacechowana obopólną życzliwością od wielu lat polsko-czeska współpraca historyków zaowocowała w 2011 r. powołaniem przez Polskie Towarzystwo Historyczne oraz Sdružení historiků České republiky wspólnego czasopisma (półrocznik, a obecnie kwartalnik), którego redakcja mieści się w Poznaniu, a pieczę edytorską sprawuje Wydawnictwo Adam Marszałek w Toruniu, znane z publikacji w języku polskim szeregu prac autorstwa badaczy znad Wełtawy. Autor jednej z nich, Jaroslav Pánek, obecnie czołowy w Europie znawca okresu XV-XVIII w., w dziele poświęconym obu sąsiadującym państwom napisał: „Centralną postacią stosunków między obydwoma narodami i ich elitami kulturalnymi w XVII wieku pozostał Jan Amos Komeński, któremu komeniolodzy poświęcają systematyczną uwagę (Czesi a Polska na progu czasów nowożytnych, Toruń 2014, s. 551). Wśród badaczy tej tematyki wymienia Martę Bečkovą z artykułem o nowych publikacjach tak blisko związanej z Lesznem prof. Jolanty Dworzaczkowej oraz studium Znajomość dzieł Jana Amosa Komeńskiego na ziemiach czeskich, słowackich i polskich od połowy XVII w. (Warszawa 1991). Z kolei na łamach inauguracyjnego zeszytu pisma „Historia Slavorum Occidentis” wśród postulatów badawczych przedstawiciele nauki czeskiej ważne miejsce wyznaczają zagadnienia z zakresu kontrreformacji i wpływów kultury polskiej na ziemiach czeskich oraz emigracji Jednoty do Rzeczypospolitej (s. 103).

Należy oczekiwać, że w kolejnych numerach polsko-czeskiego pisma ta tematyka znajdzie poczesne miejsce, a Jolanta Dworzaczkowa równie kompetentnych kontynuatorów. Współpraca między placówkami naukowymi Leszna oraz Narodowym Muzeum Pedagogicznym i Biblioteką imienia Jana Amosa Komeńskiego w stolicy Czech zaowocowała wymiernymi rezultatami w zakresie publikacji (należy też zauważyć, że kilka osób z Polski zostało w ostatnich latach uhonorowanych medalem za działalność na polu komeniologii, zob. „Rocznik Leszczyński” 15, 2015, s. 269-272) od 2005 r. Właśnie w tym roku stanowisko dyrektora Biblioteki objęła dr Marketa Pánková, która wcześniej zdobywała doświadczenie jako zastępca dyrektora Muzeum J.A. Komeńskiego w Uherskim Brodzie (1979-1993), a następnie - przez kilkanaście lat - w organach rządowych Republiki Czech na polu związków kulturalnych z Unią Europejską, w końcowym etapie łącząc to stanowisko z kierowaniem wspomnianym Muzeum i Biblioteką w Pradze. Przystąpiła m.in. do prac przygotowawczych nad wydaniem kilkutomowej Encyklopedii Comeniana jako dzieła mię- 
dzynarodowego zespołu. Oczekujemy jego publikacji w najbliższych kilku latach.

Istotne miejsce obok publikacji naukowych w popularyzowaniu postaci wielkiego uczonego odgrywają prace popularyzatorskie. O szerokim zainteresowaniu tą postacią świadczy liczba odwiedzających Narodowe Muzeum jego imienia w stolicy nad Wełtawą, w tym liczne wycieczki młodzieży szkolnej, dla której organizowane są specjalne artystycznie uatrakcyjnione wystawy. W 2014 r. ukazała się w czterech językach (czeski, angielski, niemiecki i rosyjski) licząca 200 stron książka pod tytułem Jan Amos Komenský v nás z ilustracjami znakomitego artysty Miroslava Huptycha. Zawiera ona - poprzez doskonale dobrane cytaty z dzieł uczonego - kompendium wiedzy o jego życiu i działalności oraz poglądach naukowych i społecznych. Zapoznając się z jego treścią pomyślałem nie bez żalu, że brakuje w nim piątej wersji językowej. Ale na takową nie musieliśmy długo czekać, jako że już w 2017 r. ukazała się w Lesznie - dzięki współpracy tamtejszego Muzeum z wydawcami wspomnianej pozycji - jej edycja polska w tłumaczeniu Elżbiety J. Baron, absolwentki Uniwersytetu Jagiellońskiego, rodzinnie związanej z Czechami, a miejscem pracy z Narodowym Muzeum Pedagogicznym im. Komeńskiego. Jest ona częstym gościem w Lesznie, podobnie jak pani dyrektor placówki w Pradze. Uroczysta promocja liczącej 93 strony publikacji Jan Amos Komeński w nas. Cytaty z dzieł Komeńskiego - inspiracja, pamięć, dziedzictwo przypadła na obchodzony w Europie jubileusz 500-lecia Reformacji (zob. recenzję w: „Przegląd Zachodni”, 2017, nr 3, s. 291-295). W tym samym roku ukazała się w Lesznie (także w wersji angielskiej) wartościowa edycja źródłowa, licząca 272 strony: Jan Amos Komeński i jego korespondencja z Cyprianem Kinnerem z Elblaga (zob. „Przegląd Wielkopolski”, 2017, nr 2, s. 75-77).

20 III 2018 r. w Muzeum Okręgowym w Lesznie z udziałem gości reprezentujących Muzeum Narodowe w Pradze otwarta została wystawa zatytułowana Fascynujący (Labirynt świata i raj serca) Jana Amosa Komeńskiego w kolażach Miroslava Huptycha, którą zaprezentowała dyrektor M. Pánková wraz z artystą od dawna związanym z twórczością XVII-wiecznego pedagoga. Tym razem zaprezentował on wielkoformatowe kolaże ilustrujące fragmenty dzieła Labirynt świata... powstałego pod koniec 1623 r., kiedy uczony znalazł schronienie w majętności jednego z rodaków na Morawach. Dzieło po raz pierwszy zostało opublikowane w osiem lat później na terenie Niemiec, a ponownie w 1663 r. w Niderlandach, zaś w ojczyźnie autora dopiero w 1782 r. (wcześniej w Polsce i w kilku innych edycjach na terenie Europy), ponieważ w monarchii Habsburgów wcześniej prześladowane było jako utwór protestancki. Wystawa leszczyńska cieszyła się znacznym powodzeniem i była udostępniana przez ponad trzy miesiące, do 30 czerwca, zwłaszcza że wraz 
z nią pojawiło się, opublikowane nakładem Narodowego Pedagogicznego Muzeum i Biblioteki w Pradze wydane w pięknej edytorskiej oprawie, dzieło Jan Amos Komenskýv českém a světovém výtvarném umění, obejmujące podobizny wielkiego Czecha w światowych sztukach plastycznych od 1642 r. do chwili obecnej. Pierwszy reprezentowany obiekt pochodzi z 1642 końcowy zaś z 2016 r. Całość łączy walory albumowe z tekstem dotyczącym miejsca „Nauczyciela Narodu” w ojczystych dziejach oraz precyzyjnymi informacjami na temat reprodukowanych ilustracji. Otwiera ją przedmowa, poprzedzona ciepłymi słowami skierowanymi do miłośników jego twórczości i jej popularyzatorów w dzisiejszych czasach oraz reprodukcjami starszych portretów pędzla mistrzów niderlandzkich.

Całość została podzielona na dziewięć części, z których pierwsza (s. 24-31) zawiera wprowadzenie dotyczące miejsca Jana Amosa Komeńskiego w historycznej pamięci i sztukach plastycznych. Tekst uzupełnia ilustracja zawierająca szkic XVII-wiecznej Europy z wykazem miejscowości (wraz z datami pobytu) związanych z jego osobą. Na obszarach Rzeczypospolitej były to obok Leszna (1628-1641, 1648-1650, 1654-1656) Elbląg, Gdańsk, Włodawa, Ostroróg i Toruń, ponadto znajdujący się wówczas poza jej granicami Szczecin. Pobytowi w Lesznie poświęca Autorka szczególną uwagę, informując o pamiątkach przechowywanych w tamtejszym Muzeum Okręgowym i innych miejscach. Druga ilustracja zawiera exlibris $\mathrm{z}$ hasłem Komeńskiego: Omnia sponte fluant, absit violentia rebus. Część druga (s. 32-101) dotyczy malarstwa, rysunku i grafiki i jest podzielona na osiem punktów w ujęciu chronologicznym, z których pierwszy ukazuje czasy XVII i XVIII, kolejna $\mathrm{XIX}$, następne XX w., dzieła powstałe za granicą oraz w latach najnowszych. Osobno została potraktowana w części 3 drobna twórczość graficzna (m.in. exlibrisy), banknoty i monety (cz. 4), plakaty (cz. 5), pomoce szkolne (cz. 6), rzeźbiarstwo (cz. 7) oraz drobna plastyka, medale i plakaty (cz. 8). Całość zamyka pięćdziesięciostronicowa cz. 9, poświęcona miejscu Komeńskiego w muzeach i galeriach. Najwięcej miejsca - co oczywiste - zajmują placówki w Czechach na czele z Pedagogicznym Muzeum Narodowym i Biblioteką w Pradze w pobliżu Hradczan przy ulicy Valdštejnskiej, założone w 1892 r., które przed ćwierćwieczem obchodziło setną rocznicę powstania.

Z tej okazji ukazała się książka poświęcona dziejom i współczesności jubilata (M. Pánková, E. Šimek, Národní pedagogické muzeum a knihovna J.A. Komenského 1892-2012. Nástin historie, Praha 2012, s. 144). Najstarsza jednak jest istniejąca od 1888 r. placówka w Przerowie, zaś wspomniane wcześniej muzeum w Uherskim Brodzie, założone w 1898 r., od 1957 r. specjalizuje się w komeniologii. Prezentowane 
dzieło zawiera też informacje o innych zbiorach w Republice Czeskiej (Praga, Brno) oraz za granicą. Zwłaszcza w Holandii, gdzie też znajduje się mauzoleum zmarłego na obczyźnie Nauczyciela Narodów. Zawiera też wraz z objaśnieniami fotografie pomników i tablic pamiątkowych, w tym zaopatrzone w angielskie streszczenie zdjęcie z uroczystej wymiany w 1957 r. między Polską i Czechami w siedzibie Muzeum Praskiego rękopisu Labiryntu świata (znajdującego się w zbiorach Biblioteki Uniwersyteckiej we Wrocławiu) w zamian za manuskrypt pomnikowego dzieła Mikołaja Kopernika (który swego czasu Jan Amos nabył w Heidelbergu).

Pośród placówek zagranicznych uwiecznionych w albumowym dziele wysoko zostało ocenione istniejące od $1949 \mathrm{r}$. Muzeum Okręgowe w Lesznie i współpraca między nim a komeniologią w Czechach, co znajduje m.in. odbicie w cytowanej publikacji Muzeum Okregowe w Lesznie, Leszno 2002, oraz w opublikowanym przez F. Hybla i K. Szymańską w 2009 r. katalogu wystawy Jan Amos Komeński a Polska (zob. s. 224).

Prezentowane dzieło stanowi wyraz hołdu rodaków dla najwybitniejszego przedstawiciela nauki w Czechach czasów nowożytnych, a zarazem jest to opus vitae Autorki, która swe życie twórcze poświęciła badaniom nad życiem i twórczością Ojca Narodu oraz popularyzowaniem jego dokonań w społeczeństwie. 